\title{
EDITORIAL
}

\section{Law Beyond Borders: Transnational Responses to Global Environmental Issues}

We are very pleased to have this opportunity to reflect on the meaning and value of transnational environmental law. In refining our views, we have benefited greatly from the diverse viewpoints presented on this question by other contributors to this issue. ${ }^{1}$ We will draw upon three of the invited articles to frame our perspective on transnational environmental law: Douglas Kysar's 'Global Environmental Constitutionalism: Getting There from Here'; Robert Lee's 'Look at Mother Nature on the Run in the $21^{\text {st }}$ Century: Responsibility, Research and Innovation'; and Ludwig Krämer's 'Transnational Access to Environmental Information'.

From here, we will illustrate the global relevance of transnational approaches by reference to a brief analysis of the complexities of climate change adaptation. The link between transnational environmental law and climate change governance is more obvious in the case of mitigation, where effectiveness is predicated on globally, or at least transnationally, concerted action. ${ }^{2}$ Transnationality, however, also characterizes legal regimes for climate change adaptation. With adaptation, the optimal level for adaptation actions varies and will often be at the local level. Yet, whether at the local, regional or international level, climate change adaptation regimes are influenced by transnational legal developments and pose significant transnational challenges, making a transnational perspective fruitful, if not essential. As an approach to law, transnational environmental law is not merely the domain of advocates of international or global environmental action. Instead, it is a way of looking at environmental law as an interconnected and interactive global network in response to interconnected, and often global, challenges.

\section{TRANSNATIONAL ENVIRONMENTAL LAW: AN OVERVIEW}

What is transnational environmental law? Why do we need a new concept in an already cluttered world of legal phraseology? One possible answer to both of these questions is that transnational environmental law is neither new nor amenable to

1 E.g., E. Fisher, 'The Rise of Transnational Environmental Law and the Expertise of Environmental Lawyers' (2012) 1(1) Transnational Environmental Law, pp. 43-52; G. Shaffer \& D. Bodansky, 'Transnationalism, Unilateralism and International Law' (2012) 1(1) Transnational Environmental Law, pp. 31-41.

2 C. Streck, 'Innovativeness and Paralysis in International Climate Policy' (2012) 1(1) Transnational Environmental Law, pp. 137-52. 
being easily defined. Instead, the concept of transnational environmental law may be a tool to organize our debates about domestic environmental law, comparative environmental law, and international environmental law. That is, framing analysis in terms of transnational environmental law may improve our understanding of how these systems come into being, exist, interact and evolve.

Considering domestic law, comparative law and international law together can be illuminating for three reasons. First, the three types of law may interact. Domestic legal solutions may be adopted elsewhere or form the basis of international agreements, while international principles may suffuse domestic systems in different ways in different places. Second, considering the three types of law together may reveal structural similarities. Domestic legal systems, particularly in federalist systems, may echo themes from international or comparative law. Third, considering the three types of law together may enable us to ask new questions - for instance, an issue that is heavily discussed in one area may turn out to have unsuspected relevance in other areas where it has been overlooked.

An example of this third type is the way in which a central debate in international law can illuminate understanding of domestic law. One of the fundamental challenges that any international environmental law scholar or teacher faces is: What do we mean when we refer to the corpus of international environmental law? When we use the term 'law', are we merely referring to international environmental institutions with legal personality and to the relatively small collection of legally binding commitments to which they give rise? If so, how do we categorize the many systems and networks to which these institutions give rise? Beyond those institutions and instruments, is there also a collection of principles, colloquially referred to as 'principles of international environmental law', that are part of the body of international environmental law? And, if we include these principles in our understanding of law, are we only referring to those few principles that have received the nod of approval from the international community as being either general principles of law or customary international law? Are other principles - such as sustainable development, the precautionary principle, the polluter pays principle and others - relegated to the status of 'soft' law or interstitial principles ${ }^{3}$ that are merely available as guiding norms in our decision-making processes? And, when we speak about international environmental law, what recognition - if any - do we accord to non-state actors and non-state normative systems? Finally, when we examine systems of international environmental law, how do we understand and account for the interactions of these international systems with regional entities like the European Union (EU), influential state actors, transnational networks and/or private parties?

Framing the discussion this way reveals the difficulty of discussing environmental law at any level without engaging with a series of questions about the lines between law and governance, the relationships between and among state, regional and international

3 V. Lowe, 'The Politics of Law-making: Are the Method and Character of Norm Creation Changing?', in M. Byers (ed.), The Role of Law in International Politics: Essays in International Relations and International Law (Oxford University Press, 2000), pp. 207-26, at 212. 
institutions and the ever important role of civil society in influencing the shape and success of our legal institutions and the governance systems to which they give rise. This analysis shows how transnational environmental law can illuminate questions of environmental law at all levels within the globalized world in which we exist.

It is into this milieu that Transnational Environmental Law (TEL) enters. Recognizing the limitations of traditional classification systems, the mission of the journal is to create a venue for more probing analyses of evolving systems of transnational environmental law and governance. In so doing, the journal creates a space for bringing together the sometimes bifurcated bodies of literature exploring domestic and international environmental law, and for looking beyond traditional Westphalian notions of the state as the sole locus of power. ${ }^{4}$ In recognizing the growing importance not just of transnational environmental law, but also the 'multilevel governance context in which contemporary environmental law unfolds', TEL recognizes that law is richer than a system of primary rules about private behaviour. ${ }^{6}$

Beyond this, however, one might ask how the journal fits within the larger body of literature on transnational law and what opportunities it offers for approaching the study of transnational environmental law with greater focus and rigour. And, most importantly, how can this journal help to improve our collective understanding of the increasingly complex landscape that defines modern environmental law?

The study of transnational law is not new. A large and evolving body of literature on transnational law attempts to define, describe and influence systems of transnational law and governance. ${ }^{7}$ Scholars explore the surge of transnational systems of governance at both the macro and micro levels and across a variety of issue areas. Within the literature, there is a general recognition that ' $[\mathrm{w}] \mathrm{e}$ live in a period of institutional innovation in transnational governance, ${ }^{8}$ as well as more focused attempts to analyze the implications of this change in particular contexts.

4 See K.W. Abbott \& D. Snidal, 'Strengthening International Regulation through Transnational New Governance: Overcoming the Orchestration Deficit' (2009) 42(2) Vanderbilt Journal of Transnational Law, pp. 501-78. For a helpful discussion of new governance in the domestic context, see B.C. Karkkainen, “New Governance” in Legal Thought and in the World: Some Splitting as Antidote to Overzealous Lumping' (2004) 89(2) Minnesota Law Review, pp. 471-97, at 472.

5 TEL Mission, available at: http://journals.cambridge.org/action/displayJournal?jid=TEL.

6 See H.L.A. Hart, The Concept of Law (Oxford University Press, $2^{\text {nd }}$ edn., 1997). Rather, we are talking about those polices, principles and rules that influence decision-making at multiple levels of governance, and we are seeking better ways to identify these norms and discover how they influence behaviour within, between and across systems. See, e.g., U. Beyerlin, 'Different Types of Norms in International Environmental Law: Policies, Principles and Rules', in D. Bodansky, J. Brunnée \& E. Hey, (eds.), The Oxford Handbook of International Environmental Law (Oxford University Press, 2007), pp. 425-48.

7 See P.H. Sand, 'The Evolution of Transnational Environmental Law: Four Cases in Historical Perspective' (2012) 1(1) Transnational Environmental Law, pp. 183. For just a few examples of the literature on transnational governance over time, see generally T. Hale \& D. Held (eds.), Handbook of Transnational Governance: Institutions \& Innovations (Polity Press, 2011); A. Slaughter, A New World Order (Princeton University Press, 2004); G. Teubner, 'Substantive and Reflexive Elements in Modern Law' (1983) 17(2) Law \& Society Review, pp. 239-86; K. Kaiser, 'Transnational Politics: Toward a Theory of Multinational Politics' (1971) 25(4) International Organization, pp. 790-817.

8 T. Hale \& D. Held, 'Editors' Introduction: Mapping Changes in Transnational Governance', in Hale \& Held (eds.), ibid., pp. 1-36, at 1. 
Transnational environmental law is only one of the many sub-fields that have branched off from the primary body of transnational law to explore the implications of global change for a specific legal system. Environmental law is part of a larger movement whereby scholars are pushing the traditional boundaries of law. Environmental scholars are joined in this intellectual endeavour by scholars in fields ranging from constitutional law, to trade law, to labour law. Part of the transnational environmental law journey, therefore, involves looking outward to question how our fellow travellers are framing and responding to common questions. By providing a venue in which to engage with other transnational scholars, this journal provides environmental scholars with fertile grounds for mutual learning.

Within the sphere of environmental law, there is ample scholarship revealing the limitations of centralized governance ${ }^{9}$ and the interdependency of evolving systems of environmental governance and the role of non-state actors therein. ${ }^{10}$ Returning to our opening question, however, it is less clear whether there is a collective understanding of the term 'transnational environmental law' that allows us to push forward with our endeavour.

As Elizabeth Fisher points out in her thoughtful contribution to this inaugural issue, 'because there has been no sustained scholarship on the issue', there is 'little in the way of a coherent understanding, ${ }^{11}$ of the nature of transnational environmental law. To this end, she emphasizes the need to consider: (1) the multitude of processes involved in crossing jurisdictional borders; (2) the need to differentiate between descriptive and prescriptive discussions of transnational environmental law, or as she suggests between 'wishful thinking and empirical analysis'; ${ }^{12}$ and (3) the importance of examining transnational environmental law against the backdrop of ongoing discussions of transnational law in other areas, while recognizing that the state remains more central in the environmental arena than in many other transnational fields. ${ }^{13}$

In their rich essay, 'Transnationalism, Unilateralism and International Law', Gregory Shaffer and Daniel Bodansky similarly emphasize the breadth of the term 'transnational environmental law'. They suggest that it encompasses 'all environmental law norms that apply to transboundary activities or that have effects in more

9 See, e.g., D.A. Farber, 'Issues of Scale in Climate Governance', in J.S. Dryzek, R.B. Norgaard \& D. Schlosberg (eds.), The Oxford Handbook of Climate Change and Society (Oxford University Press, 2011), pp. 479-89; D. Driesen, 'Choosing Environmental Instruments in a Transnational Context' (2000) 27(1) Ecology Law Quarterly, pp. 1-52, at 3-4 (suggesting that 'transnational legal process insights would greatly enrich our understanding of instrument choice to combat global environmental problems').

10 See, e.g., D. Zaelke, K. Markowitz \& M.R. Koparova, 'International Network for Environmental Compliance and Enforcement', in Hale \& Held, n. 7 above, pp.94-101, at p. 95 (suggesting that trans-governmental networks 'enable informal cooperation among government regulators, other governmental actors, international and nongovernmental organizations (NGOs), civil society and the regulated community. Informal cooperation on common environmental concerns can help resolve transboundary environmental problems, create efficiencies in the development of tools and programmes, create a level playing field for the regulated industries among countries, and ultimately foster the political will needed to reform weak implementation of environmental standards').

11 Fisher, n. 1 above, at pp. 46. Fisher notes that there have been insightful explorations of the topic but that we continue to lack a 'full-blown research paradigm', ibid.

12 Ibid., at p. 47.

13 Ibid. 
than one jurisdiction', including but not limited to 'national environmental regulation that has horizontal effects across jurisdictions', 14 'the development of standards by private actors that have effects across borders', and - at times - international law. In sum, the authors conclude that ' $[\mathrm{w}]$ hen we speak of transnational environmental law and legal process, we are concerned with the migration and impact of legal norms, rules and models across borders'. ${ }^{15}$

In these two pieces, and elsewhere throughout the inaugural issue, the contributors have rightfully called for rigorous analysis of the meaning of transnational environmental law - not for reasons of unnecessary precision but out of a fundamental respect for the richness of the topic. At the heart of these efforts is a basic recognition of how transnational systems pervade environmental law and of the value of a venue dedicated to more probing analysis of the complex suite of questions that accompany this shift.

\section{TECHNIQUES OF TRANSNATIONAL ENVIRONMENTAL LAW}

Within this emerging field of inquiry, the opinion pieces that inaugurate our discussion are wide-ranging. The pieces focus on substantive themes, but they also examine how transnational environmental systems emerge, are framed and evolve. In different ways, these opinion pieces focus on governance systems, not merely on legal rules. The key features of governance that are discussed include the constitutionalizing of key values, the role of soft law and multilevel governance, and the principle of open government.

In his provocative piece, 'Global Environmental Constitutionalism: Getting There from Here', Douglas Kysar pushes us to be more critical of the underlying assumptions that we make when we frame questions of environmental law. To this end, he advocates reframing the discussion of environmental constitutionalism - including, ultimately, global environmental constitutionalism. He argues that our existing discourse frames questions of environmental and economic trade-offs in the language of welfare economics, which 'constrain[s] and prefigure[s] our potential responses to it'. ${ }^{16}$ As a result, he argues, we fail to approach the problem 'with the sense of solemnity, humility, and possibility that it deserves' ${ }^{17}$ Recognizing the limitations of the system in which we are operating, Kysar argues for the need to 'recogniz[e] environmental law as a first-order subject - as a constitutional aspirant' ${ }^{18}$ Only by treating environmental law as deserving of constitutional recognition in its own right can we facilitate a productive dialogue.

Picking up on the importance of framing, 'Look at Mother Nature on the Run in the $21^{\text {st }}$ Century: Responsibility, Research and Innovation' by Robert Lee offers a thought-provoking analysis of the launch by the European Commission (via DG Research) of a new series of initiatives on the theme of a 'Responsible Research and Innovation Framework for the European Research Area'. Here, Lee explores the basic

14 Shaffer \& Bodansky, n. 1 above, at 32.

15 Ibid., at p. 32.

16 D.A. Kysar, 'Global Environmental Constitutionalism: Getting There from Here' (2012) 1(1) Transnational Environmental Law, pp. 83-94, at 86.

17 Ibid.

18 Ibid. 
concept of responsible research and innovation and the implications of linking the idea of responsibility to innovation. In so doing, he calls for a more intentional mapping of the contours of the framework for responsible research and innovation, including greater consideration for the role of soft law and multilevel governance in 'ordering our technological futures' ${ }^{19}$ Like Kysar, Lee demands that we be more thoughtful in how we frame the fundamental questions that drive our governance agenda.

Finally, in his piece entitled 'Transnational Access to Environmental Information', Ludwig Krämer points out that 'the [Aarhus] Convention led to the adoption of legislation on access to environmental information in all states that had adhered to the Convention, a remarkable change in the legislative position over the last 15 years' ${ }^{20}$ Efforts have been made to extend the principles of the Aarhus Convention ${ }^{21}$ internationally, but progress in disclosure of environmental information has been slow outside of the EU and countries like the United States (US) that have general policies in favour of disclosure of government information. Elsewhere, 'administrations continue to consider that disclosure of information on the environment is and should be the exception and that administrative confidentiality or secrecy is the rule. ${ }^{22}$ Even within the $\mathrm{EU}$, disclosure is spotty for 'ex post evaluations of legislations or practices, monitoring results and assessments, and impact studies'. ${ }^{23}$ Krämer calls for regional agreements and efforts by the EU and the US to promote the principles of the open society. Although he finds few prospects for a global international agreement, he sees hope for these transnational efforts to move national practices. By including Wikileaks within his discussion, he also flags the capacity of non-governmental actors to destabilize the status quo and stimulate activity by stakeholders.

Together, these three pieces issue a powerful call for transformations in the way that we approach questions of environmental protection. They highlight connections between environmental regulation and methods of governance in a way that is often lost when the focus is purely on substantive issues within a given legal regime. In so doing, they illustrate the powerful potential of transnational environmental scholarship.

\section{EMERGING TRANSNATIONAL CHALLENGES: CLIMATE CHANGE ADAPTATION}

Few issues reveal the multi-dimensional nature of the challenges confronting environmental law and the value of a transnational approach better than global climate change. And few issues pose more of a challenge to existing governance mechanisms

19 R.G. Lee, 'Look at Mother Nature on the Run in the $21^{\text {st }}$ Century: Responsibility, Research and Innovation' (2012) 1(1) Transnational Environmental Law, pp. 105-17, at 117.

20 L. Krämer, 'Transnational Access to Environmental Information' (2012) 1(1) Transnational Environmental Law, pp. 95-107, at 97.

21 Convention on Access to Information, Public Participation in Decision-making and Access to Justice in Environmental Matters (Aarhus Convention), Aarhus (Denmark), 25 June 1998, in force 30 Oct. 2001, available at: http://www.unece.org/env/pp/welcome.html.

22 N. 20, at p. 101.

23 Ibid. 
or to traditional boundaries around legal systems. Thus, the subject cries out for a transnational analysis.

Climate change is a global problem, but it stems from local emissions and its impacts are felt differently in different locations. Thus, the problem spans geographic scales from the rural village or urban neighbourhood to the planet. The problem also slices across traditional boundaries. For instance, issues of water supply or flood control often involve multi-jurisdictional watersheds. This poses a conundrum for policy-makers. How should responsibility for addressing climate change be divided, coordinated, and enforced among governmental entities ranging from municipalities to international institutions? What factors influence the decision ${ }^{24}$ And how can private actors, ranging from non-governmental organizations (NGOs) to insurance companies, be involved in structuring the response to climate impacts?

Climate change requires us to consider what types of governance options are available when the conventional framework is failing. In particular, it requires innovative responses to an environmental problem that is characterized by extreme heterogeneity, ${ }^{25}$ in terms of needs, capacities and challenges across levels of governance. The dimensions of the governance challenge become especially clear in the context of climate change adaptation.

The Intergovernmental Panel on Climate Change (IPCC) defines adaptation as an 'adjustment in natural or human systems in response to actual or expected climatic stimuli or their effects, which moderates harm or exploits beneficial opportunities'. ${ }^{26}$ In the legal literature, climate change adaptation has been similarly characterized as those efforts 'designed to increase the resilience of natural and human ecosystems to the threats posed by a changing environment'. ${ }^{27}$ Recent reports highlighting the inevitability of some degree of climate change have prompted increased attention to adaptation planning. The urgency surrounding adaptation has grown, with the IPCC cautioning that ' $\mathrm{r}$ ]ecent climate changes and climate variations are beginning to have effects on many other natural and human systems', ${ }^{28}$ and with the US Congressional Budget Office warning that 'the world is committed to some degree of warming from emissions that have already occurred, and even very aggressive emissions restrictions are unlikely to halt the growth of concentrations for many years to come'. ${ }^{29}$ As a result,

24 Farber, n. 9.

25 See, e.g., D. Victor, Collective Action at Local and Global Scales: The Next Collaborative Agenda, 13 Aug. 2011, available at: http://ssrn.com/abstract=1910816.

26 M.L. Parry, et al. (eds.), Climate Change 2007: Impacts, Adaptation and Vulnerability: Contribution of Working Group II to the Fourth Assessment Report of the Intergovernmental Panel on Climate Change (IPCC, Cambridge University Press, 2007), at p. 6, available at: http://www.ipcc-wg2.gov/AR4/website/ intro.pdf.

27 R.L. Glicksman, 'Climate Change Adaptation: A Collective Action Perspective on Federalism Considerations' (2010) 40(4) Environmental Law, pp. 1159-93, at 1159.

28 'Summary for Policymakers', in Parry, et al. (eds.), n. 26 above, at p. 9, available at: http://www.ipcc.ch/ pdf/assessment-report/ar4/wg2/ar4-wg2-spm.pdf.

29 Congressional Budget Office, Uncertainty in Analyzing Climate Change: Policy Implications, 1 Jan. 2005, at p. 36, available at: http://www.cbo.gov/ftpdocs/60xx/doc6061/01-24-ClimateChange.pdf. 
we are witnessing increased efforts to develop roadmaps for responding to adaptation governance challenges in both the developed and developing world. ${ }^{30}$

The art of adaptation governance differs fundamentally from the traditional methods of governance employed - or, at least, called for - within the mitigation context. Mitigation efforts to date have approached climate change as a collective action problem calling for centralized, consensus-based, top-down, decision-making systems. In the adaptation context, there has been early and continuing recognition that adaptation efforts will require greater diversification and, often, decentralization of decision-making authority. Yet, beyond recognizing the growing urgency of adaptation actions and the inherently transnational nature of the challenge, the legal literature has not yet clarified how to fill the governance gaps, particularly at the global level. ${ }^{31}$ That is, we continue to grapple with the question of how to facilitate something other than a top-down system of adaptation governance or, on the flip side, fragmentary and uncoordinated local efforts.

For all of these reasons, adaptation is a challenge that lies firmly within the realm of transnational environmental law. It is also an area where governance debates and discrete adaptation efforts are still in their infancy, and complexity defines both the relevant existing legal systems and the adaptation process itself, lending itself to sustained inquiry. Moving forward, there is a practical need to embrace complexity as a defining feature of the system and a potential advantage in terms of structuring legal and political responses.

There are theoretical tools available to aid in this inquiry, including legal pluralism and polycentric theory. Drawing upon Paul Berman's notion of legal pluralism as offering a theoretical construct for approaching the 'global legal system [as] an interlocking web of jurisdictional assertions by state, international, and non-state normative communities', 32 we can identify the inadequacies of legal centralism and identify the contours of a more complex set of overlapping legal systems. Similarly, by viewing climate governance as taking place within a polycentric system, or one that 'exists when multiple public and private organizations at multiple scales jointly affect

30 See United Nations Framework Convention on Climate Change (UNFCCC), Climate Change: Impacts, Vulnerabilities and Adaptation in Developing Countries (2007), available at: http://unfccc.int/resource/ docs/publications/impacts.pdf (noting the particular vulnerabilities of developing countries to climate change).

31 While still small, there is a very thoughtful and rapidly growing body of literature considering various questions of adaptation policy at the domestic level. See, e.g., V. Flatt, 'Adapting Laws for a Changing World: A Systemic Approach to Climate Change Adaptation' (2012) 64(1) Florida Law Review, pp. 269-93; H. Doremus, 'Adaptive Management as an Information Problem' (2011) 89 North Carolina Law Review, pp. 1455-95; R.K. Craig, "“Stationarity is Dead” - Long Live Transformation: Five Principles for Climate Change Adaptation Law' (2010) 34(1) Harvard Environmental Law Review, pp. 9-73; Glicksman, n. 27 above, at 1159; A.E. Camacho, 'Adapting Governance to Climate Change: Managing Uncertainty Through a Learning Infrastructure’ (2009) 59(1) Emory Law Journal, pp. 1-78, at 26-7.

32 P. Schiff Berman, 'Global Legal Pluralism' (2007) 80(5) Southern California Review, pp. 1155-238, at 1159 . 
collective benefits and costs', 33 we can envision the development of interconnected multilevel, multi-scalar systems.

Theoretical calls to recognize and enable hybridity offer a helpful starting point, but they are not enough. We need to consider more carefully the fragmented institutional mechanisms, the multiplicity of actors, and the diverse systems of norms that exist and interact to shape the field within which adaptation efforts take place. This kind of careful analysis is a necessary prerequisite to creating functional and transferrable multilevel, multi-scalar adaptation governance systems within a reasonable timeframe. It is just this type of analysis, however, that challenges traditional notions of both domestic and international environmental law scholarship and has been under-represented in existing legal forums.

The opinion pieces we discussed earlier could prompt new questions about climate adaptation or reframe familiar questions. Building on Kysar's work, we might ask to what extent a right to protection against climate impacts should be given constitutional status. Like Lee, we might ask about techniques for fostering responsible innovation, such as the development of new crops in response to climate change. We might also follow him in asking about the roles of soft law and multilevel governance, and about how the concept of responsibility might be linked with adaptation efforts. And like Krämer, we might want to focus on the open society and ask how openness may be crucial for effective climate adaptation.

In their own ways, each of these papers also calls for rethinking basic concepts, which in this case might prompt us to ask what exactly we mean by 'adaptation' to climate change. In particular, we might be led to inquire about the need to go beyond targeted responses to particular climate impacts and engage in a broader rethinking of societal resilience and transnational governance.

Confronting an increasingly complex legal and political landscape, intellectual rigour and honesty becomes of the utmost importance. With respect to climate change adaptation and other modern environmental challenges, Transnational Environmental Law offers space to engage with the complexity that underlies the law and policy-making process. It provides an essential forum for the rich, evolving scholarship on transnational legal issues.

Cinnamon Carlarne and Daniel Farber Editors

33 E. Ostrom, 'Nested Externalities and Polycentric Institutions: Must We Wait for Global Solutions to Climate Change before Taking Action at Other Scales?' (2012) 49(2) Economic Theory Journal, pp. 353-69, at 3. See also J. Black, 'Constructing and Contesting Legitimacy and Accountability in Polycentric Regulatory Regimes', LSE Law, Society and Economy Working Papers 2/2008, available at: http://papers.ssrn.com/sol3/papers.cfm?abstract_id=1091783 (defining polycentric systems as 'those in which the state is not the sole locus of authority, or indeed in which it plays no role at all. They are marked by fragmentation, complexity and interdependence between actors, in which state and non-state actors are both regulators and regulated, and their boundaries are marked by the issues or problems which they are concerned with, rather than necessarily by a common solution'). 